\title{
Nucleolar organiser regions as a marker of growth rate in squamous cell carcinoma of the lung
}

\author{
Shosaku Abe, Noriaki Sukoh, Shigeaki Ogura, Hiroshi Kunikane, Naomi Watanabe, \\ Isao Nakajima, Hironori Takekawa, Yoshikazu Kawakami
}

\begin{abstract}
Background The numbers of nucleolar organiser regions (AgNORs) per cell has been considered as an indicator of the cellular proliferative activity. A study was carried out to examine whether AgNOR numbers relate to the growth rate in squamous cell carcinoma of the lung.

Methods AgNORs were stained by a one step silver method, and examined in representive parafin sections from 45 cases of squamous cell carcinoma of the lung treated by surgical resection of the primary tumour.

Results The mean (SD) AgNOR numbers per cell in squamous cell carcinomas $(5.3(0.9))$ were significantly higher than those in normal bronchial epithelium $(1 \cdot 2$ $(0 \cdot 1))$. There was no statistical difference among tumours of different post-suirgical stages (stage $I=5 \cdot 2(0.8), \quad I I=5 \cdot 9(1 \cdot 4)$, III $A=5 \cdot 5(1 \cdot 3))$. The tumour volume doubling time in these cases ranged from 74 to 208 days $(120 \cdot 7(40 \cdot 4))$. There was a high inverse correlation between the AgNOR numbers and doubling time.

Conclusion The AgNOR numbers were related to the growth rate of squamous cell carcinoma of the lung. Thus the AgNOR count could be used as a useful marker for investigating the cellular proliferative activity.
\end{abstract}

(Thorax 1992;47:778-780)

Third Department of Medicine, Sapporo Medical College, South 1, West-16, Chuo-ku, Sapporo 060 $S$ Abe

First Department of Medicine, School of Medicine, Hokkaido University, Sapporo 060 Japan

N Sukoh

$S$ Ogura

H Kunikane

N Watanabe

I Nakajima

H Takekawa

Y Kawakami

Reprint requests to: DrS Abe

Received 10 October 1991

Returned to authors

6 December 1991

Revised version

9 April 1992 Accepted 14 April 1992 ciated with NORs and include RNA polymerase I, C23 protein (nucleolin), and B23 protein. ${ }^{12}$ The number of AgNORs in the cell is believed to reflect nucleolar activity and to be related to cellular proliferative activity. ${ }^{3}$ Recently AgNOR numbers have been used to compare cells in normal, hyperplastic, benign, borderline, and malignant conditions. ${ }^{4-6}$ There was a significant difference in AgNOR numbers between malignant cells and cells from other lesions. We reported that the AgNOR numbers were inversely correlated with the tumour cinoma. ${ }^{7}$
In this study we investigated the relation between AgNOR numbers and growth rate in squamous cell carcinoma of the lung.

\section{Methods}

Specimens of squamous cell carcinoma of the lung from 45 patients were chosen at random from routine files in the first department of medicine of Hokkaido University. Ages ranged from 54 to 79 (mean 66) years, and only two of the 45 were women. All patients were treated by surgical excision. The post-surgical histopathological findings and post-surgical stage were diagnosed according to the classification of the World Health Organisation ${ }^{8}$ and the International Union Against Cancer classification. ${ }^{9}$ Thirty three patients had post-surgical stage I carcinoma $T_{1} N_{0} M_{0} 14$ cases, $T_{2} N_{0} M_{0} 19$ cases), four patients stage II, and eight patients stage III A. The tissue sections were cut into slices $4 \mu \mathrm{m}$ thick and AgNOR staining was performed by a one step silver staining method. ${ }^{6}$ Briefly, the specimens were exposed for 40 minutes at room temperature in the dark to a freshly prepared solution of one part $2 \%$ gelatin solution in $1 \%$ aqueous formic acid to two parts $50 \%$ aqueous silver nitrate solution, and washed with deionised water, dehydrated, and mounted. AgNORs were seen as distinct, silver positive, intranuclear black dots, and were examined under an oil immersion lens at a magnification of 1000 . One hundred cancer cells chosen at random were assessed by two authors (SA and NS) independently, and the mean number of AgNORs per cell was calculated for each specimen. The growth rate in squamous cell carcinoma was evaluated from at least two conventional posteroanterior chest radiographs with an interval of more than three months. The tumour volume doubling time (DT) was calculated by using Meyer's formula, ${ }^{10}$

$$
\mathrm{DT}=t \times \log 2 / 3 \times \log \left(\mathrm{D}_{t} / \mathrm{D}_{0}\right),
$$
volume doubling time in lung adenocar-

\section{Results}

The number of AgNORs in the cells of the squamous cell carcinomas of the lung ranged from 3.6 to 7.5 (mean (SD) $5.3(0.9)$ ). The mean (SD) numbers of AgNORs in the tumour 
Numbers of nucleolar organiser regions ( $A g N O R s$ ) and doubling time of tumour volume in patients with squamous cell carcinoma of the lung

\begin{tabular}{llclr}
\hline Case No & Age $(y)$ & P-stage & $\begin{array}{l}\text { Noof AgNORs } \\
(\text { mean }(S D))\end{array}$ & $\begin{array}{l}\text { Doubling time } \\
\text { (days) }\end{array}$ \\
\hline 1 & 70 & I & $5 \cdot 8(1 \cdot 4)$ & 112 \\
2 & 79 & I & $5 \cdot 3(1 \cdot 2)$ & 89 \\
3 & 63 & I & $5 \cdot 0(1 \cdot 6)$ & 61 \\
4 & 66 & I & $4 \cdot 3(1 \cdot 6)$ & 174 \\
5 & 63 & I & $5 \cdot 6(1 \cdot 5)$ & 74 \\
6 & 60 & I & $5 \cdot 4(1 \cdot 6)$ & 77 \\
7 & 71 & I & $5 \cdot 1(1 \cdot 7)$ & 109 \\
8 & 61 & I & $6 \cdot 1(1 \cdot 4)$ & 94 \\
9 & 56 & I & $3 \cdot 6(1 \cdot 2)$ & 104 \\
10 & 64 & I & $5 \cdot 3(1 \cdot 0)$ & 166 \\
11 & 70 & I & $4 \cdot 5(1 \cdot 1)$ & 128 \\
12 & 72 & III A & $4 \cdot 9(1 \cdot 3)$ & 129 \\
13 & 58 & III A & $5 \cdot 5(1 \cdot 3)$ & 169 \\
14 & 67 & III A & $5 \cdot 3(1 \cdot 2)$ & \\
15 & 69 & II A & $4 \cdot 6(1 \cdot 2)$ & \\
\hline
\end{tabular}

P-stage-post-surgical stage. ${ }^{89}$

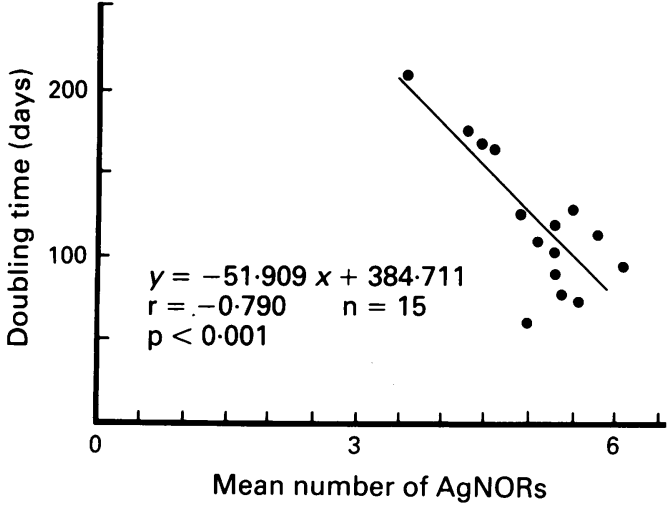

Figure 2 Relation between the numbers of nucleolar organiser regions as shown by the AgNOR method and the tumour volume doubling time in 15 patients with squamous cell carcinoma of the lung $(r=-0.79$, $p<0.001$ ). cells in post-surgical stages I, II, and III A were $5.2(0.8), 5.9(1.4)$, and $5.5(1.3)$. There was no statistical difference among the three groups. In stage $I$ the mean number of AgNORs was $4.8(0 \cdot 8)$ for $T_{1} N_{0} M_{0}$ tumours and $5.4(0.9)$ for $T_{2} N_{0} M_{0}$ tumours. The mean number of AgNORs per cell was a little greater for $T_{2} N_{0} M_{0}$ tumours than for $T_{1} N_{0} M_{0}$, but the difference between the two groups was not significant. Estimation of doubling time was available for 15 of these 45 patients with squamous cell lung carcinoma. The mean numbers of AgNORs and the doubling times of the study patients are shown in the table. The doubling times of these patients ranged from 74 to 208 (mean (SD) $120 \cdot 7(40 \cdot 4)$ ) days. The mean number of AgNORs per cell ranged from 3.6 to $6 \cdot 1(5 \cdot 2(0 \cdot 7))$. Figure 1 shows the typical staining pattern of AgNOR dispersal. The relation between AgNOR numbers and doubling time is shown in figure 2. A high inverse correlation was observed between the mean number of AgNORs and doubling time $(\mathrm{r}=-0.79, \mathrm{p}<0.001)$

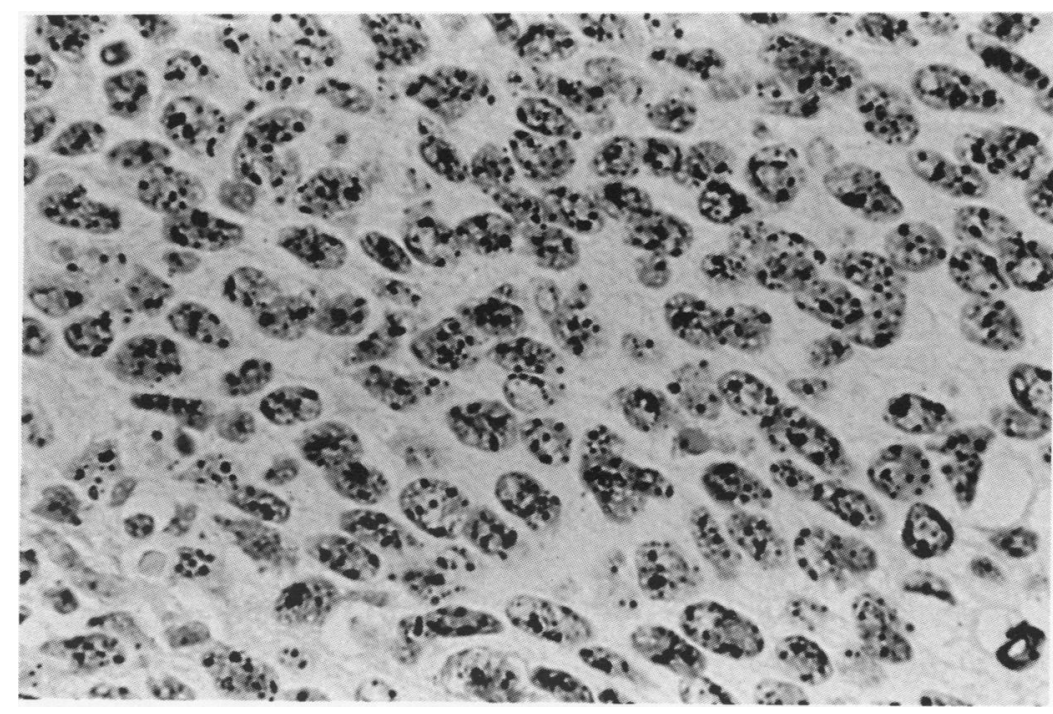

Figure 1 Squamous cell carcinoma of the lung stained by the AgNOR silver staining method to show the nucleolar organiser regions. All cells contain multiple AgNOR dots, with a mean count of $5 \cdot 3$.

\section{Discussion}

Although conventional clinicopathological staging or histological grading, or both, may be useful in the clinical assessment of lung cancer, these methods do not determine the growth rate of the tumour in individual patients. The tumour growth rate has been estimated by the cellular proliferative activity of the tumour. The proliferative activity probably best reflects the potential biological aggression, so that it is an important factor in the clinical behaviour of malignant tumours, and knowing the proliferative activity of cancer cells seems valuable. The growth rate of lung cancers has been estimated by measuring the diameter of the tumour shadow on a chest radiograph ${ }^{10}$; determining the thymidine labelling index ${ }^{11}$; analysis of DNA content ${ }^{12}$; and immunostaining with monoclonal antibodies, such as proliferating cell nuclear antigen, ${ }^{13}$ DNA polymerase $\alpha,{ }^{14} \mathrm{Ki}-67,{ }^{15}$ and bromodeoxyuridine. ${ }^{16}$ Immunohistochemical techniques are very useful for measuring cellular proliferative activity, but these techniques are not suitable for clinical practice.

Recently NORs have been detected by AgNOR staining, ${ }^{17}$ because this technique of one step silver staining is simple and quick and can be applied to paraffin embedded specimens. Crocker $e t a l^{5}$ first applied this technique to the assessment of grades of non-Hodgkin's lymphoma, and reported that the mean number of AgNORs per nucleus of high grade lymphomas was much greater than that of low grade nonHodgkin's lymphomas. Other studies have been made of the histocytological differentiation of benign breast lesions from malignant breast lesions ${ }^{18}$ and benign melanocytic skin lesions from malignant melanoma. ${ }^{4}$ The AgNOR numbers per cell have been shown to reflect the nuclear and cellular activity. Crocker et al reported that the mean number of AgNORs per nucleus is closely correlated with the percentage of $S$ phase cells as estimated by DNA flow cytometry in 20 non-Hodgkin's lymphomas. ${ }^{19}$ Raymond and Leong found a positive relation between the mean number of AgNORs per nucleus and the percentage of monoclonal antibody $\mathrm{Ki}-67$ positive cells in 83 malignant breast tumours. ${ }^{20}$ Derenzini et al 
showed that the AgNOR numbers were related to the growth rate of neuroblastoma cells. ${ }^{21}$ These results showed that AgNOR numbers are closely related to the proliferative activity of tumour cells. Recently Boldy et al reported that the mean AgNOR count is not of prognostic value in postoperative patients with squamous cell carcinoma of the bronchus. ${ }^{22}$ Previously we have shown that the mean number of AgNORs is correlated with the doubling time as estimated by conventional chest radiography in 13 patients with adenocarcinoma of the lung. ${ }^{7}$ But there was no significant relation between the mean AgNOR count and survival. ${ }^{23}{ }^{24}$

In the present study we showed that the mean number of AgNORs was satisfactorily related to the doubling time of squamous cell carcinoma of the lung. The doubling time in adenocarcinoma of the lung ranged from 80 to 760 (mean 267) days, and that in squamous cell carcinoma from 74 to 208 (mean 120) days. The doubling time was shorter in squamous cell carcinoma than in adenocarcinoma. These results are similar to those of previous reports, ${ }^{25}$ but the reason for the difference between the doubling times in these two diseases has not yet been clarified. The mean number of AgNORs ranged from 1.8 to 6.3 (mean (SD) $4.0(0.8)$ ) in adenocarcinoma and from 3.6 to $7.5(5 \cdot 3(0.9))$ in squamous cell carcinoma. The mean number of AgNORs was thus greater in squamous cell carcinoma than in adenocarcinoma. These findings clearly suggest greater proliferative activity in squamous cell carcinoma cells.

Our study shows that AgNOR numbers are related to the growth rate of squamous cell carcinoma of the lung, and can be used as a marker of the cellular proliferative activity.

1 Egan MJ, Crocker J. Evaluation of nucleolar organizer

regions in pulmonary pathology. Thorax 1990;45:225-32.
Och R, Bush H. Further evidence that phosphoprotein $\mathrm{C} 23(110 \mathrm{KD} / \mathrm{pH} 5 \cdot 1)$ is the nucleolar staining protein. $\operatorname{Exp}$ Cell Res 1984;152:260-5.

3 Field DH, Fitzgerald PH, Sin FY. Nucleolar silver staining patterns related to cell cycle phase and cell generation of PHA stimulated human lymphocytes. Cytobios 1984;41: 23-33.

4 Leong A, Gilham P. Silver staining of nucleolar organizer regions in malignant melanoma and melanotic nevi. Hum Pathol 1989;20:257-62.

5 Crocker J, Nar P. Nucleolar organizer regions in lymphomas. J Pathol 1987;151:111-9.

6 Abe S, Ogura S, Kunikane H, Sukoh N, Watanabe N, Nakajima I, et al. Nucleolar organizer regions in pre- cancerous and cancerous lesions of the bronchus. Cancer $1991 ; 67: 472-5$.

7 Ogura S, Abe S, Sukoh N, Kunikane H, Nakajima I, Inoue $\mathrm{K}$, et al. Correlation between AgNORs and the growth rate in lung adenocarcinoma. Cancer 1992;70:63-8.

8 World Health Organization. The World Health Organization histologic typing of lung tumors. Am J Clin Patho 1982;77:123-36.

9 UICC International Union Against Cancer. TNM classification of malignant tumours. 3rd ed. Geneva: Springer, 1987 41-5.

10 Meyer JA. The concept and significance of growth rate in human pulmonary tumors. Ann Thorac Surg 1972;14: 309-22.

11 Muggia FM, Krezoski SK, Hansen HH. Cell kinetic studies in patients with small cell carcinoma of the lung. Cancer 1974;34:1683-90.

12 Isobe $\mathrm{H}$, Miyamoto $\mathrm{H}$, Shimizu $\mathrm{T}$, Haneda $\mathrm{H}$, Hashimoto $\mathrm{M}$, Inoue $\mathrm{K}$, et al. Prognostic and therapeutic significance of the flow cytometric nuclear DNA content in non-small cell lung cancer. Cancer 1990;65:1391-5.

13 Robbins BA, Vega D, Ogata K, Tan EM, Nakamura RM Immunohistochemical detection of proliferating cel nuclear antigen in solid human malignancies. Arch Patho Lab Med 1987;111:841-5.

14 Namikawa $R$, Ueda $R$, Suchi T, Itoh G, Takahashi T. Double immunoenzymatic detection of surface phenotype of proliferating lymphocytes in situ with monoclona antibodies against DNA polymerase- $\alpha$ and lymphocyt membrane antigens. Am J Clin Pathol 1987;87:725-31.

15 Weiss LM, Strickler JG, Medeiros LJ, Gerdes J, Stein H, Warnke RA. Proliferative rates of non-Hodgkin's lymphomas as assessed by $\mathrm{Ki}-67$ antibody. Hum Pathol 1987; 18:1155-9.

16 Sugihara H, Hattori T, Fukuda M. Immunohistochemica detection of bromodeoxyuridine in formalin fixed tissues. Histochemistry 1986;85:193-5.

17 Ploton D, Menager M, Jeannesson P, Himber G, Pigeon F, Adnet $\mathrm{JJ}$. Improvement in the staining and in the visualization of the argyrophilic protein of the nucleolar organizer region at the optical level. Histochem J 1986; 18:5-14.

18 Smith R, Croker J. Evaluation of nucleolar organizer region associated proteins in breast malignancy. Histopathology 1988;12:113-25.

19 Crocker J, Macartney IC, Smith PJ. Correlation between DNA flow cytometric and nucleolar organizer region data in non-Hodgkin's lymphomas. J Pathol 1988;154:151-6.

20 Raymond WA, Leong AS-Y. Nucleolar organizer regions relate to growth fractions in human breast carcinoma. Hum Pathol 1989;20:741-7.

21 Derenzini M, Pession A, Farabegoli F, Trere D, Badiali M Dehan P. Relationship between interphase nucleolar organizer regions and growth rate in two neuroblastoma cell lines. Am J Pathol 1989;134:925-32.

22 Boldy DAR, Ayres JG, Crocker J, Waterhouse JAH, Gilthorpe $M$. Interphase nucleolar organiser regions and survival in squamous cell carcinoma of the bronchus-a 10 year follow up study of 138 cases. Thorax 1991;46:871-7.

23 Abe S, Isobe H, Ogura S, Nakajima I, Watanabe N, Sukoh $\mathrm{N}$, et al. Nucleolar organizer regions, nuclear DNA content, and proliferative activity in adenocarcinoma of the lung [in Japanese]. Jpn J Thorac Dis 1991;29:1282-6.

24 Abe S, Nakajima I, Ogura S, Sukoh N, Watanabe $N$, Kunikane $\mathrm{H}$, et al. Prognostic implications of nucleolar organizer regions and type IV collagen staining pattern in adenocarcinoma of the lung [in Japanese]. HAIGAN 1991;31:923-8.

25 Straus MJ. Lung cancer: clinical diagnosis and treatment. New York: Grune and Stratton, 1977:19-32. 